\title{
Microbiological Quality and Adulteration of Pasteurized and Raw Milk Marketed in Dharan, Nepal
}

\author{
${ }^{a, b}$ Dhiren Subba Limbu*, ${ }^{a, b}$ Kamana Bantawa, ${ }^{a}$ Dil Kumar Limbu, ${ }^{a}$ Mandira Devkota, ${ }^{a}$ Monika Ghimire \\ ${ }^{a}$ Department of Microbiology, Central Campus of Technology, Tribhuvan University, Dharan, Nepal \\ ${ }^{\mathrm{b}}$ Forum for Health Research and Development (FHRD), Dharan, Nepal \\ *Corresponding email: dhiren.limbu@cct.tu.edu.np
}

\begin{abstract}
This study was aimed to evaluate the quality of raw and pasteurized milk marketed in Dharan. Milk may be contaminated with pathogenic microorganisms and a mixture of several adulterants and such milk pose a risk to consumers. The study was carried out from September 2019 to January 2020. Collected samples were tested for adulterants (starch, formalin, neutralizer and table sugar) as well as microbial quality (Total Coliform count, Total Viable Count, Thermoduric Count, Escherichia. coli and Staphylococcus aureus) as per standard guideline. The adulterants starch, formalin and neutralizer were not detected in both raw and pasteurized milk. However, table sugar was present in $45 \%$ (9 out of 20) raw milk and $90 \%$ (18 out of 20) pasteurized milk. The average Total Viable Count, Total Coliform Count and Thermoduric Count of raw milk were, $59 \times 10^{5} \mathrm{CFU} / \mathrm{ml}, 14 \times 10^{4}$ $\mathrm{CFU} / \mathrm{ml}$ and $5 \times 10^{3} \mathrm{CFU} / \mathrm{ml}$ respectively. Similarly, the average Total Viable Count, Total Coliform Count and Thermoduric Count of pasteurized milk were found to be $15 \times 10^{4}$ $\mathrm{CFU} / \mathrm{ml}, 14 \times 10^{3} \mathrm{CFU} / \mathrm{ml}$ and $4 \times 10^{3} \mathrm{CFU} / \mathrm{ml}$ respectively. E. coli was detected in $30 \%$ pasteurized milk whereas $S$. aureus was isolated from only $20 \%$. Likewise, E. coli and $S$. aureus were found in $55 \%$ and $45 \%$ of raw milk respectively. The results of the study indicated that routine monitoring of dairy industries and raw milk vendors, awareness campaign and good hygienic practice should be promoted to upgrade the quality of raw and pasteurized milk.
\end{abstract}

\author{
Article Info \\ Article history: \\ Received date: 13 August 2020 \\ Accepted date: 28 September 2020
}

\section{Keywords:}

Milk adulteration

Defective pasteurization

Milk handlers

Chemical adulterants

\section{Introduction}

Milk is known as the most complete food found in nature (Marjan et al., 2014). It is an important source of carbohydrate, proteins with all ten amino acids, immunoglobulins, essential fatty acids, and other micronutrients (Hossain et al., 2010). Buffalo milk contains $7.6 \%$ fat, $3.8 \%$ protein, $4.9 \%$ lactose, $0.78 \%$ ash and $17 \%$ total solids. Cow milk contains $4.5 \%$ fat, $3.8 \%$ protein, $4.9 \%$ lactose, $0.72 \%$ ash $13.9 \%$ total solids. That is why milk is an important part of the diet of all age group including expectant mothers (Wijesinha-Bettoni \& Burlingame, 2013). It is most likely an extremely perishable food (Sebho \& Meskel, 2018). Inappropriate handling may cause an outbreak to public health problems and economic losses, thus hygienic vigilance is essential throughout the entire milk chain starting from producer to consumer (Hayes and Boor, 2001).

Various sources are responsible for contamination of the milk that may be through cattle suffered with tuberculosis, brucellosis, and mastitis (Jay et al., 2005). Contamination may also occur from poor hygiene, contaminated utensils, milk-handlers with typhoid fever, diphtheria, dysentery, and scarlet fever (Jay et al., 2005). It is common that dairy cattle and their farm's surroundings may consist of several pathogens such as Listeria spp., Salmonella and pathogenic E. coli. Raw or inadequately pasteurized milk may contain toxin-producing E. coli, Salmonella, Listeria monocytogenes and others (Pal et al., 2016).

An adulteration is an act of purposely debasing the quality of food offered for sale either by mixing or substitution of inferior substances or by the reduction 
of some valuable ingredients (FDA, 1995). Adulterants are the substances that are added in the product for making more profit or to extend the shelf life of highly perishable goods like milk (Lateef et al., 2009). Adulterants are mostly harmful to human health and thus should be avoided (FDA, 1995). According to the Department of Food Technology and Quality Control (DFTQC) guideline for milk and milk products, milk should not contain any adulterants (DFTQC, 2011). Adulterated milk has an adverse health effect as it may contain several toxic chemicals and deprive human body of nutrients required for growth and development (Marcus, 1979). Maximization of profit can be done by milk dealers in three ways viz. dilution, extraction of useful components like milk fat which is removed as cream and addition of unwanted substances like starch and table sugar to increase SNF (Lateef et al., 2009). Middlemen are one of the important milk vendors and they may adulterate milk by mixing undesirable substances (Lateef et al., 2009). If good hygiene is not maintained, contamination of milk may come from vegetation, soil, utensils, packaging materials and beddings (Lemma et al., 2018).

Ministry of Finance, Nepal reported that Nepal's total production of milk in fiscal year 2018/19 was $1,475,333$ metric tons, in which cow milk occupied $40 \%$ and buffalo milk 60\% (MOF, 2019). Food and Agriculture Organization (FAO) reported that only about $10 \%$ of milk is estimated to be used by the recognized dairy sectors and rest $(90 \%)$ goes to the informal sector, milk vendor and small dairy cooperatives out of the total milk production in Nepal (FAO, 2010). It was reported that the marketed milk in Kathmandu valley by various dairy industries were contaminated with pathogenic microorganisms (Arjyal et al., 2004).

Presence of $S$. aureus and an intestinal commensal $E$. coli indicates the alarming public health concern. To minimize the risk of milk-borne diseases, an intense study should be done to determine the microbiological quality of milk and other chemical adulterants and their public health impact (Arjyal et al., 2004). Thus, objectives of this study were to determine the bacterial contaminants as well as an admixture of adulterants in both raw and pasteurized milk marketed in Dharan.

\section{Materials and Methods}

Between September 2019 to January 2020, a total of 20 raw and 20 pasteurized milk samples were collected. We selected this time duration as it represent both summer and winter season. Raw milk samples (500 ml, distributed at atmospheric temperature) were collected in a UV sterilized plastic bottle from different milk vendors of Dharan. Pasteurized milk (a packet of $500 \mathrm{ml}$, refrigerated) samples marketed by 5 different dairy industries namely Kamadhenu, Gaubarsha, Dudhsagar, DDC and NMC dairy were purchased from different shops. These brands were selected for study as they are being marketed in Dharan. All the samples were collected at morning (7-8), kept in ice box and transported to the laboratory. All samples were processed within 6 hours of receipt.

\subsection{Adulteration test}

Collected samples were tested for most common chemical adulterants (starch, neutralizer, table sugar and formalin) according to Manual of Methods of Analysis of Foods, Milk and Milk Products published by Ministry of Health and Family Welfare, Government of India, 2016 (FSSAI, 2016). Briefly, the tests were done as follows:

\subsection{Starch test}

Five $\mathrm{ml}$ of milk was boiled and then cooled and few drops of $1 \%$ iodine starch were added. The appearance of blue color denoted positive test.

\subsection{Neutralizer test}

$10 \mathrm{ml}$ of sample to be tested and $10 \mathrm{ml}$ of $95 \%$ alcohol was taken in test tube. Few drops of $0.1 \%$ alcoholic solution (w/v) rosalic acid was added and rossy red color indicate positive result.

\subsection{Table sugar test}

$1 \mathrm{ml}$ of milk and $1 \mathrm{ml}$ of $0.5 \%$ resorcinol solution was mixed well and placed in boiling water for 3-5 minutes. The appearance of red colour denoted positive test.

\subsection{Formalin test}

Two ml of sample to be tested was taken and gently added equal volume of $90 \% \mathrm{H}_{2} \mathrm{SO}_{4}$ containing traces of $\mathrm{FeCl} 3$ from top of the test tube. Formation of purple ring at the junction indicated the presence of formalin.

\subsection{Microbiological tests}

For microbial analysis, collected samples were processed immediately after receipt. Briefly, tests were done as follows: 


\subsection{Total Viable Count (TVC)}

TVC was performed according to Laboratory Handbook for Dairy Industry published by National Dairy Development Board (NDDB), Nepal, 2001 (NDDB, 2001). In which, serial ten-fold dilutions of the milk sample were done and TVC were determined by the pour plate method on nutrient agar and incubated at $37^{\circ} \mathrm{C}$ for 24 hours.

\subsection{Total Coliform Count (TCC)}

TCC was performed according to Laboratory Handbook for Dairy Industry published by National Dairy Development Board (NDDB), Nepal, 2001 (NDDB, 2001). Serial ten-fold dilutions of the milk sample were done and TCC were determined by the spread plate method on Mac-Conkey agar and incubated at $37^{\circ} \mathrm{C}$ for 24 hours.

\subsection{Thermoduric bacterial count (TBC)}

Thermoduric bacterial count was done following Kimberly et al. (2014).

\section{E. coli}

One loopful each of the samples from 10-1 dilution was inoculated on to MacConkey Agar (MA). The plates were incubated at $37^{\circ} \mathrm{C}$ for 24 hours. Lactose fermenting colonies on MacConkey agar were subcultured to obtain pure culture. Pure cultures were tested biochemically (catalase test, oxidase test, Indole test, methyl red test, Voges Proskauer test, citrate utilization test, triple sugar iron agar test, urease test, oxidative fermentative test for confirmation of $E$. coli as described by Isenberg (2007) and Cheesbrough (2006).

\section{S. aureus}

Identification of $S$. aureus was done according to Chakraborty, 2011. In which, one loopful of each samples was inoculated into Mannitol salt agar plates and incubated at $37^{\circ} \mathrm{C}$ for 24 hours. Identification was done based on colony characteristics, Gram's staining, catalase test, oxidase test and coagulase test.

\section{Results and Discussion}

The milk samples were tested for adulteration of starch, sugar, neutralizer, and formalin. Chemical analysis of the samples revealed that, most of the pasteurized and raw milk were adulterated with table sugar. However, starch, formalin and neutralizer were absent in both pasteurized and raw milk samples (Table $1)$.

According to the Department of Food Technology and Quality Control (DFTQC) guideline for milk and milk products, adulterants should be absent in milk (DFTQC, 2011). However, this study found $90 \%$ of the pasteurized and $45 \%$ of the raw milk samples were adulterated with table sugar. In a similar study of Parajuli et al. (2018) reported that the extent of adulteration in milk of Kathmandu valley with table sugar and soda was 10 and 55\% respectively. Findings of this shows that raw and pasteurized milk marketed in Dharan are free from neutralizers. Since the neutralizers are added to neutralize the developed acidity (which in turn is due to increased microbial activity), it can be inferred that the quality of milk sold in Dharan is completely better than that of Kathmandu valley. Table sugar is commonly used as an adulterant to increase Solids-Not-Fat (SNF) level of milk. Starch was not found as an adulterant in the study by Parajuli et al. (2018) and in this study too. The reasons behind not using starch as an adulterant could be the cost of starch.

Among the pasteurized milk (total sample 20), E. coli, Total Coliforms, Thermoduric bacteria and $S$. aureus were detected in $30 \%, 80 \%, 75 \%$, and $20 \%$ samples respectively (Table 2 ).

The average Total Viable Count (TVC) of pasteurized milk was $15 \times 10^{4} \mathrm{CFU} / \mathrm{ml}$. This result was greater than the findings of the previous study of AlMazeedi et al. (2013) where, average counts of the aerobic bacteria in the pasteurized milk from three different dairy industries were $3 \times 104 \mathrm{CFU} / \mathrm{ml}, 9 \times 101$ $\mathrm{CFU} / \mathrm{ml}$ and $5 \times 103 \mathrm{CFU} / \mathrm{ml}$ respectively. This finding also did not satisfy with international standard of European Union (EU, 2020) and Mandatory Nepalese Standard (MNS, 2016). Presence of higher load of bacteria in pasteurized milk may be due to inadequate pasteurization and post pasteurization contamination. It also indicated poor hygienic condition during packaging. Similarly, in case of raw milk (total sample 20), 55\%, 95\%, 45\% and 95\% samples were contaminated with E. coli, Total Coliforms, S. aureus and Thermoduric bacteria respectively (Table 3 ). 
Table 1: Adulterants in pasteurized and raw milk

\begin{tabular}{cccccc}
\hline Milk & Table sugar & Formalin & Starch & Neutralizer & Number of samples \\
\hline Pasteurized & $18(90 \%)$ & ND & ND & ND & 20 \\
Raw & $9(45 \%)$ & ND & ND & ND & 20
\end{tabular}

$* N D=$ Not detected

Table 3: Microbiological analysis of raw milk.

\begin{tabular}{|c|c|c|c|c|c|}
\hline Sample & TB & TVC & TCC & E. coli & S. aureus \\
\hline R1 & $5 \times 10^{3}$ & $9 \times 10^{4}$ & $16 \times 10^{5}$ & $P$ & $\mathrm{P}$ \\
\hline $\mathrm{R} 2$ & $6 \times 10^{3}$ & $11 \times 10^{4}$ & $80 \times 10^{4}$ & A & A \\
\hline $\mathrm{R} 3$ & $8 \times 10^{3}$ & $7 \times 10^{4}$ & $17 \times 10^{5}$ & A & A \\
\hline $\mathrm{R} 4$ & $6 \times 10^{3}$ & $8 \times 10^{4}$ & $27 \times 10^{5}$ & $\mathrm{P}$ & $\mathrm{P}$ \\
\hline R5 & $5 \times 10^{3}$ & $12 \times 10^{4}$ & $16 \times 10^{4}$ & $\mathrm{P}$ & $\mathrm{P}$ \\
\hline R6 & $6 \times 10^{3}$ & $44 \times 10^{4}$ & $3 \times 10^{4}$ & A & A \\
\hline R7 & $5 \times 10^{3}$ & $55 \times 10^{4}$ & $20 \times 10^{4}$ & $\mathrm{P}$ & A \\
\hline $\mathrm{R} 8$ & $5 \times 10^{3}$ & $15 \times 10^{4}$ & $8 \times 10^{4}$ & A & A \\
\hline R9 & $5 \times 10^{3}$ & $11 \times 10^{5}$ & $30 \times 10^{4}$ & A & A \\
\hline $\mathrm{R} 10$ & $7 \times 10^{3}$ & $20 \times 10^{4}$ & $5 \times 10^{4}$ & A & $\mathrm{P}$ \\
\hline R11 & $3 \times 10^{3}$ & $10 \times 10^{5}$ & $11 \times 10^{3}$ & $\mathrm{P}$ & A \\
\hline $\mathrm{R} 12$ & $3 \times 10^{3}$ & $10 \times 10^{4}$ & $9 \times 10^{5}$ & $\mathrm{P}$ & $\mathrm{P}$ \\
\hline $\mathrm{R} 13$ & $4 \times 10^{3}$ & $18 \times 10^{4}$ & $22 \times 10^{4}$ & A & $\mathrm{P}$ \\
\hline R14 & $3 \times 10^{3}$ & $58 \times 10^{4}$ & $18 \times 10^{4}$ & $\mathrm{P}$ & A \\
\hline $\mathrm{R} 15$ & $3 \times 10^{3}$ & $3 \times 10^{4}$ & $12 \times 10^{4}$ & $\mathrm{P}$ & $\mathrm{P}$ \\
\hline R16 & $4 \times 10^{3}$ & $12 \times 10^{4}$ & $11 \times 10^{4}$ & A & A \\
\hline R17 & Nil & $19 \times 10^{4}$ & Nil & A & $\mathrm{P}$ \\
\hline R18 & $6 \times 10^{3}$ & $29 \times 10^{4}$ & $18 \times 10^{4}$ & $\mathrm{P}$ & A \\
\hline R19 & $8 \times 10^{3}$ & $21 \times 10^{4}$ & $12 \times 10^{4}$ & $\mathrm{P}$ & A \\
\hline R20 & $6 \times 10^{3}$ & $11 \times 10^{4}$ & $13 \times 10^{4}$ & $\mathrm{P}$ & $\mathrm{P}$ \\
\hline $\begin{array}{c}\text { Average/Pre } \\
\text { valence }\end{array}$ & $5 \times 10^{3}$ & $59 \times 10^{5}$ & $14 \times 10^{4}$ & $55 \%$ & $45 \%$ \\
\hline
\end{tabular}

*TB (Thermoduric Bacteria), TVC (Total Viable Count), TCC (Total Coliform Count) measured on CFU/ml, $P=$ Present,$A=$ Absent

In this study, none of the samples (both pasteurized and raw) were free from bacterial contamination. The average Total Viable Count (TVC) of pasteurized and raw milk was $15 \times 10^{4} \mathrm{CFU} / \mathrm{ml}$ and $59 \times 10^{5} \mathrm{CFU} / \mathrm{ml}$ respectively. Likewise, the TVC of raw milk in our study was higher than findings of some former studies in Nepal by Dhungel et al. (2019) and Dahal et al. (2010), in Ethiopia by Tassew \& Seifu (2011), in India by Jain \& Shreevastav (2014) and in Morocco by Belbachir et al. (2015) who reported average plate count of $15 \times 10^{4} \mathrm{CFU} / \mathrm{ml}, 9.03 \times 10^{5} \mathrm{CFU} / \mathrm{ml}, 3.95 \times 10^{6}$ $\mathrm{CFU} / \mathrm{ml}, 2.34 \times 10^{6} \mathrm{CFU} / \mathrm{ml}$ and $1.4 \times 10^{6} \mathrm{CFU} / \mathrm{ml}$ respectively. The reason behind the higher occurrence rate could be related to the difference in time, place and season of research. Additionally, higher prevalence rates might be due to unhygienic processing, improper cleaning, deficient handling, and contamination of utensils. In contrast, our result was lesser than the findings of former studies by Acharya et al. (2017), Dahal et al. (2010), Aaku et al. (2004), Mwangi et al. (2000), Moustafa et al. (1988) and Mohamed \& El Zubeir (2007) who found the average value of $104.71 \times 10^{5} \mathrm{CFU} / \mathrm{ml}, 107 \mathrm{CFU} / \mathrm{ml}, 107 \times 10^{6} \mathrm{CFU} / \mathrm{ml}$, $1 \times 10^{9} \mathrm{CFU} / \mathrm{ml}$ and $5.63 \times 10^{9} \mathrm{CFU} / \mathrm{ml}$ respectively.

Table 2: Microbiological analysis of pasteurized milk

\begin{tabular}{cccccc}
\hline Sample & TB & TVC & TCC & E. coli S. aureus \\
\hline S1 & Nil & $11 \times 10^{4}$ & $16 \times 10^{3}$ & $\mathrm{P}$ & $\mathrm{P}$ \\
S2 & $5 \times 10^{3}$ & $10 \times 10^{3}$ & $18 \times 10^{3}$ & $\mathrm{~A}$ & $\mathrm{~A}$ \\
S3 & $35 \times 10^{2}$ & $5 \times 10^{3}$ & $11 \times 10^{2}$ & $\mathrm{~A}$ & $\mathrm{~A}$ \\
S4 & $5 \times 10^{3}$ & $10 \times 10^{3}$ & $3 \times 10^{3}$ & $\mathrm{~A}$ & $\mathrm{~A}$ \\
S5 & Nil & $10 \times 10^{2}$ & Nil & $\mathrm{A}$ & $\mathrm{A}$ \\
S6 & Nil & $22 \times 10^{2}$ & $2 \times 10^{3}$ & $\mathrm{~A}$ & $\mathrm{~A}$ \\
S7 & $2 \times 10^{2}$ & $11 \times 10^{3}$ & Nil & $\mathrm{A}$ & $\mathrm{A}$ \\
S8 & $18 \times 10^{2}$ & $10 \times 10^{2}$ & $21 \times 10^{3}$ & $\mathrm{~A}$ & $\mathrm{~A}$ \\
S9 & $3 \times 10^{3}$ & $19 \times 10^{3}$ & $14 \times 10^{3}$ & $\mathrm{P}$ & $\mathrm{A}$ \\
S10 & $2 \times 10^{3}$ & $18 \times 10^{3}$ & $74 \times 10^{3}$ & $\mathrm{~A}$ & $\mathrm{~A}$ \\
S11 & $5 \times 10^{3}$ & $62 \times 10^{3}$ & $36 \times 10^{3}$ & $\mathrm{P}$ & $\mathrm{A}$ \\
S12 & $5 \times 10^{3}$ & $13 \times 10^{3}$ & $2 \times 10^{3}$ & $\mathrm{~A}$ & $\mathrm{P}$ \\
S13 & Nil & $2 \times 10^{2}$ & Nil & $\mathrm{A}$ & $\mathrm{A}$ \\
S14 & $2 \times 10^{3}$ & $19 \times 10^{3}$ & $16 \times 10^{3}$ & $\mathrm{~A}$ & $\mathrm{~A}$ \\
S15 & Nil & $2 \times 10^{2}$ & Nil & $\mathrm{P}$ & $\mathrm{A}$ \\
S16 & $6 \times 10^{2}$ & $17 \times 10^{3}$ & $17 \times 10^{3}$ & $\mathrm{P}$ & $\mathrm{A}$ \\
S17 & $9 \times 10^{3}$ & $15 \times 10^{3}$ & $9 \times 10^{2}$ & $\mathrm{~A}$ & $\mathrm{P}$ \\
S18 & $10 \times 10^{3}$ & $17 \times 10^{3}$ & $11 \times 10^{3}$ & $\mathrm{P}$ & $\mathrm{A}$ \\
S19 & $10 \times 10^{3}$ & $13 \times 10^{3}$ & $5 \times 10^{3}$ & $\mathrm{~A}$ & $\mathrm{~A}$ \\
S20 & $8 \times 10^{3}$ & $14 \times 10^{3}$ & $32 \times 10^{3}$ & $\mathrm{~A}$ & $\mathrm{P}$ \\
\hline Average/ & $4 \times 10^{3}$ & $15 \times 10^{4}$ & $14 \times 10^{3}$ & $30 \%$ & $20 \%$ \\
Prevalence & & & & & \\
\hline
\end{tabular}

*TB (Thermoduric Bacteria), TVC (Total Viable Count), TCC (Total Coliform Count) measured on CFU/ml, $P=$ Present,$A=$ Absent

The differences in findings of these studies can be correlated to difference in time as well as place. Higher bacterial counts indicate poor hygiene practice and ineffective pasteurization of the milk (Harding, 1995). It suggests that proper handling of milk, improvement in sanitation, proper sterilization and disinfestations of contaminated utensils and use of safe water is mandatory for all stakeholders 
In this study, $80 \%$ of pasteurized and $95 \%$ of raw milk samples were tested positive with an average Coliform count of $14 \times 10^{3} \mathrm{CFU} / \mathrm{ml}$ and $14 \times 10^{4} \mathrm{CFU} / \mathrm{ml}$ respectively (Table 3 ). This finding was higher than some previous studies (Silva et al., 2010; El Nahas et al., 2015 and Acharya et al., 2017). The annual report published by DFTQC (2011/2012) reported that out of 65 milk and milk products analyzed, 31 (47\%) milk samples were found to be microbiologically unsafe (DFTQC, 2011). Hence, the result of this study complied with the study done by DFTQC showing that most of the milk being sold in Nepal might be microbiologically unsafe for consumption. A similar study was done by Acharya et al. (2017) and reported the Total Coliform count range from $2-52 \%$ in raw milk. The higher coliform count detected in this study may be due to poor hygiene of farm, use of contaminated water while milking and use of contaminated utensils by farmers. Since it is not practical to produce a coliform free product, the existence of coliform may not necessarily indicate direct fecal contamination of milk but it is a precise indicator of poor hygiene and sanitation during milking and further handling processes. The presence of coliforms in pasteurized milk sample may be due to defective pasteurization, adulteration of pasteurized milk with raw milk and unsanitary handling (Hassan et al., 2015).

Similarly, current study found that the prevalence of E. coli, S. aureus and Thermoduric bacteria in pasteurized milk were $30 \%, 20 \%$, and $75 \%$ respectively. Furthermore, the prevalence of E. coli, $S$. aureus and Thermoduric bacteria in raw milk were $55 \%, 45 \%$ and $95 \%$ respectively (Table 2 and 3). E. coli was reported in $18.75 \%$ and $20 \%$ of pasteurized milk samples by Acharya et al. (2017) and Parajuli et al. (2018) respectively which is just lesser than results of this study.

S. aureus contamination was detected in $12.5 \%$, $15 \%$ and $3.9 \%$ pasteurized milk (Arjyal et al., 2004; Acharya et al., 2018; and Dai et al., 2019) and this result is a bit lesser than current study (Table 2). The presence of $S$. aureus in raw milk of this study was similar with the study of Schirmer et al. (2006), but did not support the results of other studies (Joshi et al., 2014 and Silvestre et al., 2008). Presence of S. aureus in raw milk may be due to poor personal hygiene of milkers, utensils and milk handlers. The higher prevalence of $S$. aureus in pasteurized milk might be due to unhygienic processing, improper cleaning, deficient handling, and post-processing contamination of packaging material from the polluted environment (Sankhar, 2015).

This study showed the average Thermoduric bacterial count of pasteurized and raw milk were $4 \times 10^{3}$ $\mathrm{CFU} / \mathrm{ml}$ and $5 \times 10^{3} \mathrm{CFU} / \mathrm{ml}$ respectively. According to Kimberly et al., (2014) an average of $4.07 \times 10^{2} \mathrm{CFU} / \mathrm{ml}$ and $4.65 \times 10^{2} \mathrm{CFU} / \mathrm{ml}$ of thermoduric bacteria were found in raw milk in winter and summer respectively. The average value of thermoduric bacteria in pasteurized milk reported by Delgado et al., (2013) was $3.19 \times 10^{2} \mathrm{CFU} / \mathrm{ml}$ and was in a range from $2.38 \times 10^{4}$ to $6.82 \times 10^{5} \mathrm{CFU} / \mathrm{ml}$ in raw milk. The variation on the thermoduric bacteria counts can be related to the difference in time and place. The presence of thermoduric bacteria in milk indicates that the pasteurizer may be defective so that some of the milk unable to reach the up to require pasteurizing temperature; there may be a high amount of foam which is not heated to temperature; or the vats may not be washed between runs (Rogers \& Frazier, 1930).

Different reports have suggested that pasteurized milk is contaminated with food-borne pathogens and it indicated that pasteurization alone could not be a stable solution to control the milk-borne diseases (Oliver et al., 2005). Hence, all the quality assurance systems such as Good Manufacturing Practice (GMP), Sanitation Standard Operating Procedure (SSOP), and Hazard Analysis Critical Control Point (HACCP) should be implemented by industries. Our results demand further intense investigation and periodic monitoring of local milk vendors as well as dairy industries.

\section{Conclusions}

Both raw and pasteurized milks sold in Dharan were found to be free from adulteration with starch, formaldehyde and neutralizers and thus present lesser chemical safety issue, for example, compared to milk sold in Kathmandu valley. The microbiological quality of both raw and pasteurized milk are still very poor. Presence of coliforms in raw milk clearly indicated lack of hygiene and sanitation on the part of milk suppliers. The presence of coliforms, thermoduric bacteria and $S$. aureus in pasteurized milk invites several speculations, ranging from faulty processing, to post-pasteurization contamination. Pasteurization is an effective technique to reduce and eliminate food-borne 
pathogens and other bacteria from milk. However, presence of food-borne pathogens in pasteurized milk indicates that pasteurization alone is not a certain solution for controlling milk-borne pathogens. To upgrade the quality of raw and pasteurized milk, legal enforcement on the microbial guideline of marketed milk, routine monitoring of dairy industries and raw milk vendors, awareness campaign and good hygienic practice should be promoted.

\section{Acknowledgments}

Authors are thankful to the Department of Microbiology, Central Campus of Technology, Dharan for laboratory facilities. We thank Professor Basanta Kumar Rai for his excellent guidance throughout the study.

\section{Conflicts of Interest}

The authors declare that they have no conflicts of interest.

\section{Funding}

This research was funded by Dharan Submetropolitan City to the Forum for Health Research and Development, Dharan, Province-1, Nepal.

\section{References}

Aaku, E. N., Collison, E. K., Gashe, B. A., \& Mpuchane, S. (2004). Microbiological quality of milk from two processing plants in Gaborone Botswana. Food control, 15(3), 181-186.

Acharya, S., Bimali, N. K., Shrestha, S., \& Lekhak, B. (2017). Bacterial Analysis of Different Types of Milk (Pasteurized, Unpasteurized and Raw Milk) Consumed in Kathmandu Valley. Tribhuvan University Journal of Microbiology, 4, 32-38.

Al-Mazeedi, H. M., Gholoum, F. A., \& Akbar, B. H. (2013). Microbiological status of raw and pasteurized milk in the state of Kuwait. International Journal of Engineering and Science, 3(11), 15-19.

Arjyal, C., Dahal, B. N., \& Khadka, B. (2004). Microbial quality of milk available in Kathmandu valley. Journal of the Nepal Medical Association, 43(153), 137-40.

Belbachir, C., Khamri, M., \& Saalaoui, E. (2015). Microbiological quality of the raw cow milk at three rural communes of the eastern region of Morocco. International Food Research Journal, 22(4), 16751680 .

Chakraborty, S. P., Mahapatra, S. K., \& Roy, S. (2011). Biochemical characters and antibiotic susceptibility of Staphylococcus aureus isolates. Asian Pacific Journal of Tropical Biomedicine, 1, 212-216.

Cheesbrough, M. (2006). District laboratory practice in tropical countries, part 2. Cambridge university press.

Dahal, L. R., Karki, D. B. N., \& Shah, R. (2010). Total bacterial counts of raw milk in Eastern Terai of Nepal. Journal of Agriculture and Environment, 11, 46-50.

Dai, J., Wul, S., Huang, J., Wu, Q., Zhang, F., Zhang, J., Wang, J., Ding, Y., Zhang, S., Yang, X., Lei, T., Xue, L., \& Wu, H. (2019). Prevalence and Characterization of Staphylococcus aureus Isolated From Pasteurized Milk in China. Frontiers in Microbiology, 10, 641.

Delgado, S., Rachid, C. T., Fernández, E., Rychlik, T., Alegría, Á., Peixoto, R. S., \& Mayo, B. (2013). Diversity of thermophilic bacteria in raw, pasteurized and selectively-cultured milk, as assessed by culturing, PCR-DGGE and pyrosequencing. Food microbiology, 36, 103-111.

DFTCQC. (2011). Annual Report 2068. Department of Food Technology and Quality Control, Kathmandu, Nepal, Retrieved from: http://www.dftqc.gov.np/actfile/ANNUAL\%20RE PORT\%202068_1575443897.pdf [Accessed on 02 August 2020].

Dhungel, D., Maskey, B., Bhattarai, G., \& Shrestha, N. K. (2019). Hygienic Quality of Raw Cows' Milk at Farm level in Dharan, Nepal. Journal of Food Science and Technology Nepal, 11, 39-46.

El Nahas, A. W., Mohamed, H. A., El Barbary, H. A., \& Mohamed, H. S. (2015). Incidence of E. coli in raw milk and its products. Benha Veterinary Medical Journal, 29(1), 12-117.

Elmagli, A. A. O., Ibtisam, E. M., \& Zubeir, E. L. (2006). Study on the hygienic quality of pasteurized milk in Khartoum State (Sudan). Research Journal of Animal and Veterinary Sciences, 1(1), 12-17.

EU. Exporting dairy products to the European Union, Total plate count (TPC) and bulk milk cell count 
(BMCC) requirements. Department of Agriculture, Water and the Environment, Retrieved from https://www.agriculture.gov.au/export/controlledgoods/dairy/registered-

establishment/understanding-eu-requirements (Last update 4 February 2020). [Accessed on 13 August 2020].

FAO. (2010). Dairy Sector Study of Nepal. Food and Agricultural Organization of the United Nations. pp .26.

FDA. (1995). Defect Action Level Handbook. Food and Drug Administration, Center for Food Safety and Applied Nutrition. Washington, DC.,

FDA. (2015). Grade A pasteurized milk ordinance. Retrieved from https://www.fda.gov/downloads/food/guidancereg ulation/guidance documents regulatory information/ milk/ucm513508.pdf.

FSSAI. (2016). Manual of Methods of Analysis of Foods: Milk and Milk Products. Food Safety and Standards Authority of India, Ministry of Health and Family Welfare, Government of India, New Delhi.

Harding, F. (1995). Milk Quality (1st ed.). Springer US, USA,

Hassan GM, Meshref AMS and Gomaa SM. Microbiological quality and safety of fluid milk marketed in Cairo and Giza Governorates. Current Research in Dairy Sciences, 2015, 7(1), 18-25.

Hayes, M. C., \& Boor, K. (2001). Raw milk and fluid milk products. FOOD SCIENCE AND TECHNOLOGY-NEW YORK-MARCEL

DEKKER-, 59-76.

Hossain, T. J., Alam, M. K., \& Sikdar, D. (2011). Chemical and microbiological quality assessment of raw and processed liquid market milk of Bangladesh. Continental Journal of Food Science and Technology, 5(2), 6-17.

Isenberg, H. D. (2007). Clinical microbiology procedures D.C. handbook. (2nd edition), ASM press, Washington, USA.

Jay, J. M., Loessner, M. J., \& Golden, D. A. (2005). Milk, fermentation, and fermented and nonfermented dairy products. Modern Food Microbiology, 149-173.
Joshi, L.R., Tiwari, A., Devkota, S. P., Khatiwada, S., Paudel, S., \& Pande, K. R. (2014). Prevalence of methicillin-resistant Staphylococcus aureus (MRSA) in dairy farms of Pokhara, Nepal. International Journal of Veterinary science, 3(2), 87-90.

Kimberly, P. B., Ananda, S., \& Garcia, A. (2014). Prevalence of thermoduric bacteria and spores on ten mid-west dairy farms. Journal of Dairy Science, 97(11), 6777-84.

Lateef, M., Faraz, A., Mustafa, M. I., Akhtar, P., \& Bashir, M. K. (2009). Detection of adulterants and chemical composition of milk supplied to canteens of various hospitals in Faisalabad city. Pak. J. Zool, 9, 139-142.

Lemma D, H., Mengistu, A., Kuma, T., \& Kuma, B. (2018). Improving milk safety at farm-level in an intensive dairy production system: relevance to smallholder dairy producers. Food Quality and Safety, 2(3), 135-143.

Marcus, A. I. (1979). Disease prevention in America: From a local to a national outlook, 1880-1910. Bulletin of the History of Medicine, 53(2), 184-203.

Marjan, S., Das, K. K., Munshi, S. K., \& Noor, R. (2014). Drug-resistant bacterial pathogens in milk and some milk products. Nutrition \& Food Science, 44 (3), 241-48.

Mohamed, N. N. I., \& El Zubeir, I. E. M. (2007). Evaluation of the hygienic quality of market milk of Khartoum State (Sudan). Int. J. Dairy Sci, 2, 33-41.

Moustafa, M. K., Ahmed, A. A. H., \& Abdel-Hakiem, E. H. (1988). Sanitary condition of market milk in Assiut city. Assiut Veterinary Medical Journal, 19, 80-85.

Mwangi, A., Arimi, S. M., Mbugua, S., Kangethe, E. K., Omore, A. O., \& McDermott, J. J. (2000, August). Assurance of marketed milk quality in Kenya. In Faculty of Veterinary Medicine Biennial Scientific Conference, (pp. 30-31).

NDDB. (2001), Microbiological analysis of milk and milk products. In:" Laboratory Handbook for Dairy Industry." National Dairy Development Board, Kathmandu, Nepal, 233-59.

Neelu, J., \& Shobha, S. (2014). Quality Assurance of Marketed Raw Milk in Bhopal city, MP, India. 
International Research Journal of Biological Sciences, 3(11), 23-27.

Oliver, S. P., Jayarao, B. M., \& Almeida, R. A. (2005). Foodborne pathogens in milk and the dairy farm environment: food safety and public health implications. Foodbourne Pathogens \& Disease, 2(2), 115-129.

Pal, M., Alemu, J., Mulu, S., Karanfil, O., Parmar, B. C., \& Nayak, J. B. (2016). Microbial and hygienic aspects of dry milk powder. Beverage \& Food World, 43, 28-31.

Parajuli, A., Rimal, P., Maharjan, R., Chaudhary, R., \& Chaturwedi, S. B. (2018). Quality Analysis of Milk in Kathmandu Valley. Tribhuvan University Journal of Microbiology, 5, 7-10.

Rogers, L. A., \& Frazier, W. C. (1930). Significance of thermophilic bacteria in pasteurized milk. American Journal of Public Health, 20, 815-9.

Sankhar, S. (2015). Microbiological Considerations: Pasteurized Milk. International Journal of Dairy Science, 10 (5): 206-218.

Schirmer, B. C. T., Heir, E., Møretrø, T., Skaar, I., \& Langsrud, S. (2013). Microbial background flora in small-scale cheese production facilities does not inhibit growth and surface attachment of Listeria monocytogenes. Journal of dairy science, 96, 61616171.

Sebho, H. K., \& Meskel, D. H. (2018). Determination of Adulteration and Chemical Composition of Raw Milk Sold in Hossana Town, South Ethiopia. Dairy and Vet Sci J, 6(5), 555-699.

Silva, R., Cruz, A. G., Faria, J. A., Moura, M. M., Carvalho, L. M., Water, E. H., \& Sant'Ana, A. S. (2010). Pasteurized milk: efficiency of pasteurization and its microbiological conditions in Brazil. Foodborne pathogens and disease, 7, 217219.

Silvestre, D., Ruiz, P., Martinez-Costa, C., Plaza, A., \& Lopez, M. C. (2008). Effect of pasteurization on the bactericidal capacity of human milk. Journal of Human Lactation, 24(4), 371-376.

Tassew, A., \& Seifu, E. (2011). Microbial quality of raw cow's milk collected from farmers and dairy cooperatives in Bahir Dar Zuria and Mecha district, Ethiopia. Agriculture and Biology Journal of North America, 2, 29-33.

Wijesinha-Bettoni, R., \& Burlingame, B. (2013). Milk and dairy product composition. Milk and dairy products in human nutrition, 41-102.

How to cite: Limbu, D. S., Bantawa, K., Limbu, D. K., Devkota, M., \& Ghimire, M. (2020). Microbiological Quality and Adulteration of Pasteurized and Raw Milk Marketed in Dharan, Nepal. Himalayan Journal of Science and Technology, 3-4, 37-44. 